\title{
YALE
}

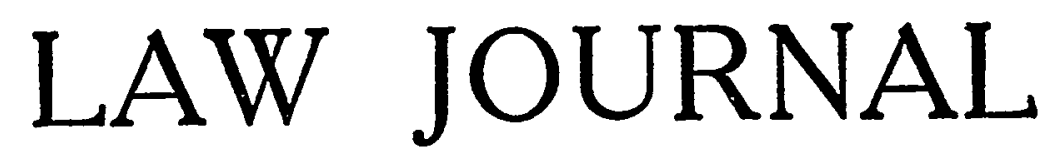

\begin{tabular}{lll}
\hline Vol. XXVII & JUNE, 1918 & No. 8 \\
\hline
\end{tabular}

\section{CONTINGENT REMAINDERS AND OTHER POSSIBILITIES}

\section{CHARLES SWEET}

Lincoln's Inn, London

In an article on the rule in Whitby $v$. Mitchell published in the Yale LAW JournaI for February, I9I7, Mr. Charles P. Sanger examines the recent cases of In re Park's Settlement, In re Bullock's Will Trusts, ${ }^{2}$ and In re Garnham, ${ }^{3}$ and suggests that the limitations which caused the difficulty in In re Park's Settlement and In re Bullock's Will Trusts were valid, not for the reasons given by Sargant, J., in the latter case, but on the ground that in applying the rule in Whitby v. Mitchell to any particular case, actual and not possible events are to be considered. This ingenious suggestion has, it is submitted, two defects: in the first place, it assumes that the rule in Whitby v. Mitchell applies to such cases as In re Park's Settlement and In re Bullock's Will Trusts, and in the second place, it is inconsistent with the origin and objects of the rule.

STATEMENT OF THE RULE IN WHITBY V. MITCHELL

The rule in Whitby $v$. Mitchell forbids the limitation of land to an unborn person and his issue in succession." You cannot limit an

${ }^{2}$ [1914] I Ch. 595.

2 [19I5] I Ch. 493 .

[I916] 2 Ch. 413.

In some text-books of great repute, the rule is said to forbid the limitation of a remainder to the unborn child of an unborn child of an existing person: Farwell, Powers (2d ed.) 286: Sugden, Powers (8th ed.) 2. This is quite inaccurate, for if land is limited to $A$. for life with remainder to the eldest 
estate to an unborn person for life with remainder to the issue of that unborn person. ${ }^{5}$ Consequently if land is limited to A., a living person, for life with remainder to $X$., a person then unborn, for life, with remainder to the issue of $\mathrm{X}$., this last remainder is void.

In In re Park's Settlement the limitations were in effect to A., a living person for life, with remainder to $X$., an unascertained and possibly unborn person, for life, with remainder to the children of A.; Eve, J., held that the remainder to the children of A. infringed "the rule against limiting land to an unborn child for life with remainder to his unborn child." At first sight it is a little difficult to understand how a limitation to the children of a living person can be a limitation to the children of an unborn person. The mystery, however, is partly explained by the fact that in In re Park's Settlement X. was the widow (if any) whom A. might leave surviving him; there was therefore a "double," not to say a "treble," possibility that A. might marry a woman unborn at the date of the settlement, and have children by her; and in that case, if she survived her husband, the limitation to the children following her life estate would, as Eve, J., put it, "offend against what has been called the rule against double possibilities, but what is more accurately described .... as the rule against limiting land to an unborn child for life with remainder to his unborn child": in other words against the rule in Whitby $v$. Mitchell. This line of argument shows the mischief which is done by that misleading expression, "the rule against double possibilities." There is, as will presently be explained, a rule which prohibits the limitation of successive contingent remainders, but there is no general rule against double possibilities.

It is fortunate for the credit of the law that In re Park's Settlement has been over-ruled by the decisions in In re Bullock's Will Trusts and In re Garnham. The reasoning of Sargant, J., in the former case shows conclusively, it is submitted, that such cases as In re Park's Settlement, In re Bullock's Will Trusts and In re Garnham, in each of which the ultimate limitation was to the children of a living person, are not within the letter of the rule in Whitby $v$. Mitchell, and the history of the rule shows that they are not within its spirit.

As for the remark of Younger, J., in In re Clarke's Settlement ${ }^{3}$ (which Mr. Sanger cites with tacit approval), expressing regret "that the American view has not prevailed in this country [England] and

grandson of B., a bachelor, this is perfectly good. The error arose from the absurd suggestion that a limitation which infringes the rule in Whitby $v$. Mitchell involves a possibility on a possibility.

'Per Kay, J., in Whitby v. Mitchell (I889) 42 Ch. D. 494,500 ; affirmed by the Court of Appeal (I890) 44 Ch. D. 85.

[III6] I Ch. 467 . 
that a rule so artificial and now without defenders or necessity [meaning the rule in Whitby $v$. Mitchell] has not been abrogated by the more modern rule against perpetuities," it may be pointed out that the remark does not display any great amount of knowledge on the subject. So far as the present writer is aware, there is no American decision with reference to the rule in Whitby $v$. Mitchell; if there had been any decision to the effect that the rule in question has been abrogated by the modern rule against perpetuities, Mr. J. C. Gray would hardly have failed to chronicle the fact. ${ }^{8}$ On the other hand, the legislature of Massachusetts has recently passed a statute declaring that remainders shall in future be governed by the rule against perpetuities, "exclusively of any other supposed rule respecting limitations to successive generations or double possibilities." It seems unlikely that the legislature would have taken this trouble if the rule in Whitby $v$. Mitchell had been treated as "abrogated" by the American courts. And as for the rule being "artificial and without necessity," the learned judge is respectfully advised to read the Third Report of the Real Property Commissioners; he will perhaps then be able to understand the necessity for the rule and its great practical importance when it was first laid down.

\section{POLICY OF THE RULE IN WHITBY V. MITCHELL}

Independently of the question whether the rule in Whitby $v$. Mitchell applies to such cases as In re Park's Settlement and In re Bullock's Will Trusts, Mr. Sanger makes the suggestion that, in every case to which the rule applies, we must have regard to actual and not to possible events. Speaking with all respect, the suggestion seems inconsistent with the origin and object of the rule.

Mr. Sanger argues by analogy. He points out that a legal contingent remainder (assuming it to be valid in its creation) does not fail if in the result it vests at or before the determination of the particular estate; in other words, the question whether it will take effect or not depends on actual and not on possible events. Mr. Sanger argues that the same principle applies to all rules governing legal contingent remainders, and that where land is limited to $X$.,

TThe case of Whitby $v$. Mitchell is not even mentioned in the chapter on "Perpetuities" in Mr. Alfred G. Reeves' Real Property, Special Subjects (I904) referred to in complimentary terms by Mr. J. C. Gray, Perpetuities (3d ed.) 262.

'In the first edition of his Rule against Perpetuities published in I886, three years before Whitby v. Mitchell was decided, Mr. J. C. Gray pronounced the rule (established by that decision as a rule of long standing) to be "a nonexistent rule based on an exploded theory," and he steadfastly maintained this view until the last: Mr. J. C. Gray, Whitby v. Mitchell once more (I913) 29 LAW QUAR. REV. 304. 
an unascertained person, for life, with remainder to his issue, and if when $X$. is ascertained it turns out that he was born at the time when the settlement took effect, the remainder to his issue is not invalidated by the rule in Whitby $v$. Mitchell. It is extremely improbable that the question will ever arise, because in ninety-nine cases out of a hundred when land is limited to an unborn person, the limitation takes the form of a limitation to the child of a named individual who has no child at the time. In other words, the person to take under the limitation is necessarily unborn at the date of the settlement. But casting probabilities on one side, it is possible to imagine a case raising the point. Suppose a testator seised of land in fee simple devises it to A., a living person, for life, with remainder, if he leaves a widow surviving him, to that widow for life, with remainder to her children born within twenty-one years after A.'s death. A. marries a woman who was born in the testator's lifetime: she survives $A$. and dies leaving children born within the required period; whether they are children by $A$. or by a subsequent husband is immaterial. Is the devise to the children good? Mr. Sanger says "Yes." The present writer ventures to think that in the particular case the limitations to the widow and children would be successive legal contingent remainders, and that the devise to the children would be bad under the rule recognized by the Court of King's Bench in Chapman v. Brozen: If, however, the limitations were equitable, the rule in Chapman v. Broum would not apply, and it is submitted that the devise to the children would be good, because the rule in Whitby $v$. Mitchell was never intended to apply to such a case.

However this may be, there seem to be two answers to Mr. Sanger's theory that the rule in Whitby $v$. Mitchell is like the rule requiring a contingent remainder to vest in due time, and that its operation therefore depends on actual and not on possible events.

In the first place, the two rules compared by Mr. Sanger rest on different principles. The rule requiring a legal contingent remainder to. vest at or before the determination of the particular estate, and allowing it to take effect if in the result it does so vest, is a technical rule derived from the doctrine of seisin. It does not apply to equitable contingent remainders.

"The reason why a contingent remainder under a legal devise failed, if at the death of the previous holder of the estate of freehold there was no person who answered the description of the remainderman next to take, was the feudal rule that the freehold could never be vacant, for that there must always be a tenant to render the services to the lord, and therefore if the remainder could not take effect immediately on the determination of the prior estate, it never could take effect at all. This result of feudal rules was never held to apply

\footnotetext{
-Post, p. 985 et seq.
} 
to equitable estates, and it was sometimes said that the legal estate in the trustee supported the remainder. That was not the best mode of expressing the doctrine, the principle really being that as the legal estate in the trustees fulfilled all feudal necessities, there being always an estate of freehold in existing persons who could render the services to the lord, there was no reason why the limitations in remainder of the equitable interest should not take effect according to the intention of the testator. If, at the time of the determination of the prior equitable estate of freehold, there was no person capable of taking, a person afterwards coming into existence within the limits of the rule of remoteness, and answering the terms of the gift, was allowed to take."10

And in the same case, Lord Justice Cotton remarked that "in equity the feudal rules of tenure will not be allowed to defeat the trusts which the testator has declared by his will."11

The rule in Whitby $v$. Mitchell, on the other hand, is quite different in its origin and object. It has nothing to do with feudal doctrines; ;2 $^{12}$ it had its origin in the well-grounded fear of perpetuities caused by the persistent endeavors of landowners in the sixteenth and seventeenth centuries to make perpetual settlements by limiting their land to unborn generations for successive life estates. It is difficult for us at the present day, even in England, to realize the dangers of unbarrable entails, and to appreciate the "abhorrence" which they inspired in the minds of the judges, ${ }^{13}$ but no one who investigates the history of the subject can have any doubt that what we call the rule in Whitby $v$. Mitchell was directed against attempts to create "perpetuities" or unbarrable entails. This is explained with perfect clearness by the Real Property Commissioners ${ }^{14}$ and by Mr. Charles Fearne. ${ }^{15}$ Mr. Joshua Williams expressed the same idea when he said, in speaking of the rule afterwards established by the decision in Whitby $v$. Mitchell:

${ }^{20}$ Per Jessel, M. R, in Abbiss v. Burney (I88I) I7 Ch. D. 2II, z29.

"Ibid. 23I.

13 The reader must not allow himself to be misled by the extraordinary statement made by Lopes, L. J., in his judgment in Whitby $v$. Mitchell that the rule established by that case was "an old rule originating out of the feudal system." In commenting on this statement $\mathrm{Mr}$. T. Cyprian Williams remarked: "What a travesty of legal history is this!" Contingent Remainders and the Rule agairst Perpetuities (I8g8) I4 LAW QUAR REV. 234, 244. The expression is not too strong. The first suggestion of the rule in Whitby $v$. Mitchell is to be found at the end of the sixteenth century in the refusal of the courts to allow "uses of perpetual freeholds." Charles Sweet, Limitations of Land to Unborn Generations (1913) 29 LAW QUAR. REv. 304, 307.

${ }^{13}$ See 2 Bl. Com. Ir6; Jarman, Wills (6th ed.) 28r et seq.

${ }^{14}$ Third Repert (1833) 29. The passage is printed in extenso in an article by Charles Sweet, The Rule in Whitby v. Mitchell (Igra) 72 Coldusara Law REv. I99, 204-5.

${ }^{25}$ Contingent Remainders, 502: also printed at p. 20I of the article referred to in note 14, and in 29 LAW QUAR. REV. 304, 317. 
"It may not be sufficient to restrain every kind of settlement which ingenuity might suggest, but it is directly opposed to the great motive which usually induces attempts at a perpetuity, namely the desire of keeping an estate in the same family and it has accordingly been hitherto found sufficient." ${ }^{\text {16 }}$

Mr. Burton states the law in similar language:

"Life estates may by law be given in succession to any number of persons in existence, and ulterior estates in succession to their children yet unborn. . . . B But no remainder can be given to the child of a person who is not in existence. For if this were once allowed, no limit could be assigned to the extension of contingent remainders through the remotest generations, and it would be easy to accompany these, for their preservation, with other remainders to persons ascertainable in due time as trustees, so as to make the settlement perpetual: and thus all the political inconveniences which attended entails in their first creation would be renewed."17

In other words, the rule in Whitby v. Mitchell, like all rules directed against attempts to make property inalienable, is a rule of public policy, and when a limitation or other disposition of property offends against a rule of public policy it is void $a b$ initio, without regard to actual events. As Mr. Charles Fearne puts it, such a limitation "is by our courts considered void in its creation; as in the case of a limitation of lands in succession, first to a person in esse, and after his decease to his unborn children, and afterwards the children of such unborn children, this last remainder is absolutely void." 18 When Mr. Charles Fearne says that it is "absolutely void" he means that it is void $a b$ initio, and that no subsequent event can make it good. This quality of being a rule of public policy distinguishes the rule in Whitby v. Mitchell from the rule allowing a legal contingent remainder to take effect if it vests at or before the determination of the preceding estate of freehold. The latter rule does not involve any question of public policy; it is a technical rule derived from feudal doctrines.

In the second place, Mr. Sanger is evidently under the impression that the rule in Whitby $v$. Mitchell was originally designed to restrict the creation of contingent remainders, and that it only applies to them. for he describes it as "an old rule dealing with contingent remainders." In this he appears to have been misled by the only statement of the rule which is given by $\mathrm{Mr}$. Charles Butler, namely, that "if land is limited to an unborn person during his life, a remainder cannot be limited so as to confer an estate by purchase on that person's issue!"'10

${ }^{36}$ Real Property (3d ed.) 227 (12th ed.) 274. The passage does not appear in the editions published in more recent years.

${ }^{17}$ Burton, Compendium, 255.

${ }^{18}$ Fearne, Cont. Rem. (1826) 502.

${ }^{19}$ Note to Fearne, Cont. Rem. (Ioth ed.) 565. 
Similar statements of the rule are given by Mr. Joshua Williams, ${ }^{20}$ Mr. Burton ${ }^{21}$ and Mr. Stephen M. Leake. ${ }^{22}$ And it is true that the first example given by Mr. Fearne of the application of the rule is a limitation by way of remainder:

"In the case of a limitation of lands in succession, first to a person in esse, and after his decease to his unborn children, and afterwards the children of such unborn children, this last remainder is absolutely void." 23

But it is to be noted, first, that this passage occurs not in that part of Mr. Fearne's work which treats of contingent remainders, but in that part which deals with executory interests; second, that he begins by saying that the rule applies to "any limitation in future or by way of remainder;" and third, that as a further illustration of the application of the rule he cites Humberston $v$. Humberston, ${ }^{24}$ where lands were demised to a corporation upon trust to convey them to certain persons and their male descendants one after another successively in perpetuity, so that no one should take more than an estate for life; these trusts, which were certainly not contingent remainders, were held to infringe the rule in question, because, in the language of Mr. Fearne, they tended to create a perpetuity or unbarrable entail, ${ }^{25}$ but in order to give effect to the testator's intention as far as possible (cy-près) the first unborn sons were held to take ordinary barrable estates tail.

The devise in Humberston $v$. Humberston was one of many attempts made to create unbarrable estates tail by limiting successive estates for life to unborn generations. At first it was hoped that this might be done by way of use, but the courts soon held that such uses were not executed by the statute. ${ }^{28}$ Shortly afterward, when executory bequests of terms of years were held to be valid, attempts were made to bequeath them in strict settlement to named persons and the heirs of their bodies. Entails of this kind, if they had been lawful, would

\footnotetext{
${ }^{\infty}$ Real Prop. (12th ed.) 274.

' Compendium, 256.

Prop. in Land (Ist ed.) 333-4

${ }^{23}$ Cont. Rem. (1826) 502.

${ }^{24}$ (I716) I P. Wms. 332.

$\approx$ In the last edition of his Rule against Perpetuities, I66, note, Mr. J. C. Gray did me the honor of accepting this explanation of Humberston v. Humberston as accurate, but he could not bring himself to see that the doctrine of cy-près is an exception to the rule forbidding the creation of unbarrable entails, and not to the modern rule against perpetuities: see Rule against Perpetuities, 650; Charles Sweet, Limitations of Land to Unborn Generations (I913) 29 LAW QUAR. REv. 304.

${ }^{*}$ Charles Sweet, Limitations of Land to Unborn Generations (19r3) 29 LAw QUAR. REv. 307 et seq.
} 
have been unbarrable, but the courts refused to allow them. ${ }^{27}$ Then the experiment was tried of devising land to trustees in fee upon trust for certain persons and their male issue or descendants forever, each to take for 99 years if he should so long live ${ }^{28}$ or of limiting land in strict settlement by way of entail, subject to a term of 1000 years vested in trustees upon trust, in the event of any tenant in tail barring the entail, to raise $\mathbb{5}_{5000}$ and pay it to the person next in remainder. ${ }^{29}$ These experiments failed. Another device was to settle land in strict settlement subject to a power of revocation given to trustees, with a direction that on the birth of a tenant in tail they should reduce his estate to a tenancy for life with remainder to his sons in tail, "and thus by creating a succession of estates for life by way of substitution for the original estates tail to create a direct perpetuity. This contrivance also failed of effect." ${ }^{30}$

It is therefore clear that the principle on which the rule in Whitby $v$. Mitchell is based applies to executory trusts of freeholds, ${ }^{31}$ to reversionary equitable terms of years, ${ }^{32}$ to appointments under powers, ${ }^{33}$ and to executory bequests of long terms, ${ }^{34}$ as well as to contingent remainders. It has been decided that it applies to equitable contingent remainders..$^{35}$

Why, then, it may be asked, do such learned text-writers as Charles Butler, Burton, Joshua Williams and Leake state the rule in Whitby $v$. Mitchell as one which applies only to contingent remainders? The answer is that Mr. Charles Butler introduced confusion into the subject by mixing up two doctrines supposed to have been laid down in Lord Coke's time-namely, the rule against remote possibilities or contingencies, and the rule against double possibilities or a possibility on a possibility. It requires some patience to unravel the tangle.

\footnotetext{
"Leventhorpe v. Ashbie (I635) I Roll. Abr. Devise I, pl. I. In Stanley v. Leigh (I732) 2 P. Wms. 686 where an entail of this kind was attempted, Jekyll, M. R., remarked that "the law does equally abhor a perpetuity" whether the subject of it is land held in fee simple or land held for a long term of years.

${ }^{23}$ Beard v. Westcott (1813) 5 Taunt 393; Somerville v. Lethbridge (1795) 6 T. R. 213.

$\Rightarrow$ Maimwaring v. Baxter ( 1800 ) 5 Ves. 458.

${ }^{\text {so }}$ Real Prop. Commissioners, Third Report, 30. Cf. Duke of Marlborough $v$. Godolphin (I759) I Eden, 404.

"Humberston $v$. Humberston, supra, note 25.

2 Beard v. Westcott and Somerville v. Lethbridge, supra, note 28.

"Duke of Marlborough v. Godolphin, supra, note 30.

"Stanley v. Leigh, supra, note 27.

" Monypenny v. Dering (1852) 2 DeG. M. \& G. I45; In re Nash [1910] I Ch. I. If it had been a technical rule applying to legal contingent remainders, there would have been no reason to extend it to equitable contingent remainders, for they are subject to the modern rule against perpetuities.
} 
VARIETIES OF POSSIBILITIES

There is a certain ambiguity in the term "possibility," because sometimes it means a contingent or uncertain event, and at other times an interest in property which depends on a contingency. Thus a contingent remainder is not an estate, but the possibility of having an estate at some future time. ${ }^{36}$

We find in the old books at least three distinct doctrines with regard to possibilities laid down or suggested:

I. In the Rector of Chedington's Case, ${ }^{37}$ Popham, C. J., said that a lease for years could not commence "upon a contingent which depended upon another contingent," but the case was decided on other and quite sufficient grounds, and Popham's dictum, so far from being supported by the authority which he cites, ${ }^{38}$ was treated as inaccurate by Lord Coke $\mathrm{e}^{39}$ and by Lord Nottingham, who said:40

"That there may be a possibility upon a possibility, and that there may be a contingency upon a contingency, is neither unnatural nor absurd in itself, but the contrary rule given as a reason by my Lord Popham in the Rector of Chedington's Case looks like a reason of art, but in truth has no kind of reason in it, and I have known that rule often denied in Westminster Hall."

The correct opinion seems to be that there is no general principle of law which invalidates a limitation on the ground that it involves a possibility on a possibility. There are, however, two specific rules which have this effect:

(a) Estates upon condition. In former days, before the introduction of uses and trusts and before contracts were specifically enforceable in equity, conditions were used to create future estates. But the courts kept a watchful eye upon them lest they should be used to restrict the free alienation of land.41 Hence Lord Coke lays down the rule that, if an estate is granted subject to the performance of a condition, a further estate cannot be granted to take effect on the performance of an additional condition, because the first estate is "but in contingency, which is not a foundation upon which a greater [estate] can increase, for a possibility cannot increase upon a possibility."12 This doctrine is now of no practical importance, because the desired result can generally be attained by means of a use, trust,

- Challis, Real Prop. (3d ed.) 76.

" (1598) I Co. I53 a, 156 a.

- See Gray, Perpetuities, sec. 126.

- Blandford v. Blandford (1675) I Rolle R. 318, 321.

- Duke of Norfolk's Case (1647) 3 Ch. Cas. 1, 29.

a Charles Sweet, Restraints on Alienation (July, 1917) 33 LAw QUAR REv. 236, 237.

- The Lord Stafford's Case (1609) 8 Co. 73 a, 75 a. 
or covenant, subject of course to the restrictions imposed by the modern rule against perpetuities.

(b) Successive contingent remainders. In I694 a testator who desired that his lands should continue in his name and blood "so long as it shall please God to permit the same," devised them to his nephew William Brown, son of the testator's brother Reginald Brown, for his life, with remainder to his sons in tail male, with remainder to the second son of Reginald Brown for life, and after the death of such second son then to the first son of the body of such second son of Reginald Brown and to the heirs male of the body of such second son. Thomas Brown, the second son of Reginald Brown, was born after the testator's death, but during the life of William Brown, who died without having had a son; the devise to Thomas Brown as the second son of Reginald therefore took effect, but the question arose whether he took an estate for life or an estate in tail male. The case was submitted to several learned counsel, who differed in their views. Mr. Wilbraham's opinion, dated October 29 th, 1746 , is instructive:-

"I take it clearly that the testator intended to limit his estate to the second son of Reginald unborn, and that he intended to make him tenant for life, with a contingent remainder to his first and other sons in tail.*3 This I think is not within the rules of law, for though the law may allow a contingent remainder possibly for one life, yet I incline to think that it will not allow a contingent remainder upon a contingent remainder, so that the limitation to the first son of the second son of Reginald, I think, was not legal; for the limitation to the second son of Reginald was a contingent remainder, and if the law should allow another contingent remainder to be limited upon the first, the law might allow another upon that, and so on in infinitum, which would lock up real property longer than the policy of the law will admit, and would tend to perpetuity. I therefore incline to think that the limitation to the first son of the second son of Reginald, which second son was not then in esse, was not a legal but a void limitation. If this limitation be a void limitation, then leaving out or rejecting it, the limitation will run thus to the second son of Reginald for life and to the heirs male of the body of such second son lawfully to be begotten,' which would I think create an estate tail.",4

The case subsequently came before the courts and they decided it in accordance with the opinion of Mr. Wilbraham and Mr. Booth. The Court of King's Bench said that even if they supplied the omission in the will by inserting a limitation to the heirs of the body of the first son of Thomas, this would not effectuate, but defeat, the intention of the testator, because such a limitation would be void. Both

\footnotetext{
- It was clear from the whole frame of the will that some words had been accidentally omitted after the devise to the first son of the body of the second son of Reginald, and that the testator intended to give him an estate in tail
male.

"Cases and Opinions, ii, 426-7. Mr. Booth was of the same opinion: ibid. 428.
} 
Lord Mansfield and Wilmot, J., said that a possibility cannot be limited upon a possibility. ${ }^{45}$ Now a contingent remainder, as everyone knows, is not an estate, but the possibility of having an estate at some future time; and therefore in saying that a possibility cannot be limited upon a possibility, what the learned judges meant was that a contingent remainder cannot be limited so as to follow and be dependent on the vesting of a preceding contingent remainder. As Thomas Brown was unborn at the testator's death, the devise to him was contingent, and although it vested on his birth, the succeeding contingent remainder which the testator intended to give to his eldest son was beyond the limits allowed by law for the creation of such possibilities, and was therefore void. That this is the true doctrine is clear from the opinion given by $\mathrm{Mr}$. Yorke in advising on a later case in which he thus stated the law : ${ }^{8}$

"A contingent remainder must vest during the life or immediately upon the death of the devisee of the particular estate which precedes it, such devisee being in esse at the time when the will speaks, but it cannot be made to wait or expect the vesting of another estate, prior in limitation and equally contingent with itself. The law does not allow a contingency to depend upon a contingency, or one possibility to be thus raised upon another."

It is submitted that In re Frost, ${ }^{4 \pi}$ referred to in Mr. Sanger's article, was rightly decided on the ground that the limitations in that case involved successive contingent remainders. ${ }^{49}$

II. Lord Coke has some remarks with regard to limitations of estates tail, which but for the great reputation of their author might fitly be described as arrant nonsense:

"If lands be given to a man which hath a wife and to a woman which hath a husband and the heires of their two bodies, they have presently [that is, immediately] an estate taile, for the possibility that they may marry ..... But if lands be given to a man and two women and the heires of their bodies begotten, in this case they have a joynt estate for life and every of them a severall inheritance, because they cannot have one issue of their bodies, neither shall there be any construction a possibility upon a possibility, viz.? that he shall marry the one first and then the other."19

4 Chapman v. Brown (1765) 3 Burr. 1626, affd. by the House of Lords in accordance with the unanimous opinion of the judges: 3 Bro. P. C. 269 . It is remarkable that the doctrine which we call the rule in Whitby $v$. Mitchell was not referred to. See Charles Sweet, The Rule in Whitby v. Mitchell (Ig09) 25 LAW QUAR. REV. 385, 397-8.

- Cases and Opinions, ii, 440.

त (I889) 43 Ch. D. 246.

- Williams, Real Prop. (22d ed.) 422.

- Co. Litt. 25 b. There is a passage at $184 a$ to the same effect, and in Lampet's Case (I6ro) 10 Co. $46 \mathrm{~b}, 50 \mathrm{~b}$, Lord Coke develops the point at some length. 
It is indeed obvious that they cannot have one issue of their bodies; this is a sufficient explanation of the construction put upon the limitation, and it is difficult to see why Lord Coke should drag in the doctrine of a possibility on a possibility, for supposing that the man married first the one woman and then the other, and had a child by each of them, how could this affect the question?

The truth is that the question in the case supposed by Lord Coke is purely a question of construction, and the rule stated by him is an instance of the willingness of the judges in early days to adopt a benignant construction in order to give effect to the presumed intention of the parties.

III. In Cholmley's Case, ${ }^{50}$ the judge laid down the doctrine that a contingent remainder cannot be limited on a remote possibility.

"A possibility which shall make a remainder good ought to be a common possibility and potentia propinqua, as death, or death without issue, or coverture, or the like. And therefore as the logician saith, potentia est duplex, remota et propinqua; the remainder to a corporation which is not at the time of the limitation of the remainder, is void, although such be erected afterwards during the particular estate, for it was potentia remota; and this plainly appears in a common case in our books. If a lease be made for life, the remainder to the right heirs of J. S., this is good, for by common possibility J. S. may die during the life of the tenant for life; but if at the time of the limitation of the remainder, there is no such J. S., but during the life of the tenant for life J. S. is born and dies, his heir shall never

It will be noticed that there is not a word here about a double possibility, or a possibility on a possibility, for when it is said that potentia est duplex, remota et propinqua, this of course means that possibilities are of two kinds, remote and near. ${ }^{51}$ Yet for some reason which has never been explained, our most learned real property lawyers persist in regarding the case put by Lord Coke of a remainder limited to the heirs of J. S., a nonexistent person, as one involving a double possibility or possibility on a possibility, the reason given being that

"it amounts to the concurrence of two several contingencies... first that such a person as J. S. should be born, which is very uncertain, and secondly that he should also die during the particular estate,

" (I597) 2 Co. 50, 5I b.

The reader must not resent this somewhat obvious explanation of the meaning of duplex; that it is not wholly uncalled for appears from the fact that even so learned a writer as Mr. Joshua Williams thought that duplex meant "double;" for in commenting on the doctrine laid down in Cholmley's Case, Mr. Williams says that "the chance that a married woman shall have a son named Geoffrey is stated to be a double or remote possibility," as if "double" were the same as "remote." There is not a word about double possibilities in Cholmley's Case. 
which is another uncertainty grafted upon the former. This is called a possibility upon a possibility, which Lord Coke tells us is never admitted by intendment of law.",

The learned writer does not seem to have noticed that his explanation does not fit the first example given by the court in Cholmley's Case of a remote possibility, namely that of a limitation to a nonexistent corporation; there is no possibility upon a possibility here. ${ }^{s s} \mathrm{Mr}$. Fearne's explanation is a blunder, pure and simple.

The real reason why the judges in the sixteenth century were afraid of remote possibilities was that at that time contingent remainders were of comparatively recent introduction, for they were unknown to the original common law, ${ }^{54}$ and the judges were apprehensive that they might be made use of for the purpose of tying up land by restricting its alienation. This fear proved to be groundless, partly because every contingent remainder was liable to be destroyed by the owner of the particular estate, and partly because the doctrine of seisin made it necessary that every contingent remainder should vest at or before the determination of the particular estate. It follows from this latter rule that the nature of the contingency on which a remainder is limited to take effect is quite immaterial, for whether the event is almost a certainty or whether it is wildly improbable, the period within which it must happen is the same; if it happens at or before the determination of the particular estate the remainder takes effect, otherwise the remainder fails, but in neither case does the improbability or remoteness of the contingency postpone the vesting, or affect the alienability of the land. It is not clear at what period this simple truth dawned upon the judicial mind, ${ }^{55}$ but it must have been before 1843, for in that year Lord St. Leonards, in a passage which has puzzled those who fail to connect it with the doctrine supposed to be laid down in Cholmley's Case, stated clearly that the doctrine of remote possibilities had long ceased to be a rule of English law:so

" Fearne, Cont. Rem. 25I ; Third Report of Real Prop. Comm. 29; I Preston, Abstracts, I28. Even Mr. J. C. Gray, usually so critical and clear-sighted, makes the same blunder: Perpetuities, Igr.

a "The true ground ... seems to be that the gift to a corporation while in fact no such corporation exists . . . is void for want of capacity or uncertainty." Preston, Abstracts, 128.

- Littleton thought they were impossible, having regard to the doctrine of seizure. See sec. 72I, and Lord Coke's commentary.

* It was perceived by the Real Property Commissioners in 1833: Third Report, 29.

- Cole v. Sewell (1843) 4 Dr. \& Wal. I, 28-29. See Charles Sweet, The Rule in Whitby v. Mitchell (rgog) 25 LAw QUAR. REv. 385, 394; Charles Sweet, Remoteness of Terms and Powers (I9I4) 30 LAW QUAR. REv. 66, 76. 


\section{ERROR AND CONFUSION}

Having regard to the very obvious criticisms to which the doctrine of remote possibilities and the doctrine of a possibility upon a possibility are open, it is difficult to understand, first, how Mr. Fearne could have brought himself to repeat the obsolete nonsense uttered by the judges in Cholmley's Case as establishing a rule still applying to contingent remainders, and second, how he could have mixed up this nonsense with the still greater nonsense written by Lord Coke to explain the construction of a limitation to the heirs of the bodies of a man and two women, for it is with reference to this latter question that Lord Coke tells us, in the passages referred to by Mr. Fearne, that a possibility upon a possibility is never admitted by intendment of law. ${ }^{37}$ He does not use the expression with reference to contingent remainders.

Mr. Charles Butler, in annotating Mr. Fearne's treatise; pointed out that "the expression of a possibility upon a possibility, which in the language of Lord Coke cited in this place ${ }^{58}$ is never admitted by intendment of law, must not be understood in too large a sense," and he went on to demonstrate that a remainder may validly be limited so as to depend on a possibility upon a possibility, ${ }^{59}$ but he failed to notice that Lord Coke does not use the expression with reference to contingent remainders; the question whether a limitation to a man and two women and the heirs of their bodies gives them an estate for life or an estate tail has nothing to do with contingent remainders; it is a mere question of construction.

Not content with this confusion, Mr. Butler, in a note on strict settlements of land contained in the last edition of Mr. Fearne's treatise, made confusion worse confounded. He pointed out, quite accurately, that before the introduction of executory interests no question of remoteness, or (as he calls it) perpetuity, could arise, because future estates could only be created by way of remainder, and that the remoteness of a remainder, however great, was no objection to it. He went on to say: ${ }^{: 0}$

"The case of a possibility on a posssibility may be considered as exceptions from the rule. They proceeded on a different ground, and gave rise to this important rule, that if land is limited to an unborn person during his life, a remainder cannot be limited so as to confer an estate by purchase on that person's issue."

\footnotetext{
"Ante, pp. 988-9.

Mr. Fearne's reference is to Co. Litt. $25 b, 184 a$.

-Mr. Preston gave an instance of a remainder being validly limited on a treble possibility: Abstracts, 128 .

- Fearne, Cont. Rem. (1oth ed.) 565.
} 
It follows that Mr. Butler made three blunders:

(i) He mixed up Lord Coke's ridiculous theory that the reason why a limitation to the issue of the bodies of three persons does not give them a single estate tail is because it involves a possibility on a possibility, with the doctrine laid down by the judges in Cholmley's Case (but now happily exploded) that a remainder cannot be limited to take effect on a remote contingency.

(ii) He thought that the rule which we call the rule in Whitby $v$. Mitchell was derived from the curious mixture thus produced.

(iii) He therefore concluded that the rule in question only applies to remainders.

In this singular combination of error, Mr. Butler has been followed by many later writers on the law of real property.

\section{CONCLUSIONS}

A careful study of the history of the subject leads, it is submitted, to these conclusions:

I. There is no general principle of law that a limitation which involves a possibility on a possibility is bad.

"The cases given in illustration of this [supposed doctrine] may be easily accounted for on principles of law, without resorting to the quaint and unintelligible terms of a possibility on a possibility."

Two rules of the common law for which this doctrine is given as the reason ${ }^{\text {ss }}$ are really due to the instinctive distrust of complicated limitations entertained by the early judges. Since the invention of the modern rule against perpetuities no extension of the doctrine in question is likely to be made. ${ }^{\text {t4 }}$

II. The rule in Whitby $v$. Mitchell has nothing to do with the supposed rule against a possibility on a possibility. It is derived from the general principle forbidding the creation of unbarrable entails, which down to the time of Mr. Fearne were called "perpetuities."

a Williams, Real Prop. (I2th ed.) 272; Challis, Redl Prop. (3d ed.) II6. The present writer is constrained to admit that his respect for the distinguished authors here criticized long prevented him from attempting to solve the mystery.

i I Preston, Abstracts, 128.

- Supra, p. 985 et séq.

"In re Bowles [1902] 2 Ch. 650.

"According to Mr. Fearne, the rule that if a life estate is given to an unborn person no estate in remainder can be given to his issue, is an instance of the application of the general principle that any limitation in future "which in its nature tends to a perpetuity" is void in its creation: Cont. Rem. 502. Mr. Fearne does not anywhere, it is believed, use "perpetuity" as equivalent to "remoteness." No one who thinks that those terms were interchangeable in the eighteenth century can understand Mr. Fearne's treatise. 
III. The rule in Whitby $v$. Mitchell is a rule of public policy, being a branch of the general principle of law which forbids limitations savoring of perpetuity or remoteness. Consequently every limitation which infringes it is void $a b$ initio, and subsequent events cannot make such a limitation good.

It is difficult to predict how the courts will deal with the questions raised by Mr. Sanger. - Having regard to the decision of the House of Lords in Cadell v. Palmer, ${ }^{B 6}$ it may well be that our judges will consider it conclusively settled that the rule in Whitby $v$. Mitchell does not apply. to executory bequests of terms of years. On the other hand, there seems no reason why our judges should abrogate the rule recognized by the Court of King's Bench and apparently the House of Lords in Chapman v. Brown, more especially as it justifies the decision in In re Frost. Nor does it seem probable that any court will adopt Mr. Sanger's suggestion that the application of the rule in Whitby $v$. Mitchell depends on actual events, unless the court altogether disregards the origin and object of the rule.

* (I833) I C. \& F. 372. In an article on Contingent Renainders (Jan. 1917) 30 HArv. L. REv. 226, Mr. J. L. Thorndike points out that a series of executory devises of a long term of years to unborn generations, confined within the limits allowed by the rule against perpetuities, was held to be valid by the House of Lords in Cadell v. Palmer. This decision upheld the judgment of the court below, which was commented on by the Real Property Commissioners in their Third Report, 33. The main question in Cadell v. Palmer was whether the period of $2 \mathrm{r}$ years allowed by the modern rule against perpetuities must have reference to the minority of a person taking under the settlement, or whether it may be a term in gross: the House of Lords decided in favor of the latter allowance. Mr. Gray says that "the result seems to have been arrived at by accident rather than by any process of judicial reasoning," and elsewhere refers to "the curious and illogical manner" in which this extension was made. Perpetuities, ss. 186, 223. But he does not seem to have noticed that the decision in Cadell $v$. Palmer was partly based on a misapprehension of Beard v. Westcott; the limitations in that case were void because, as the Real Property Commissioners and Mr. Fearne pointed out, they tended to create a "perpetuity" in the sense of an unbarrable entail; they would have been void if the modern rule against perpetuities had never been invented. 